\title{
Türkiye Sineması'nda Hapsedilmişliğin Güncel Temsilleri: Abluka ve Sarmaşık
}

\author{
Ar. Gör. Dr. Gülsenem GÜN
}

galatasaray üniversitesi iletişim fakültesi gcobaner@gsu.edu.tr

\begin{abstract}
Representations of Imprisonment in Turkish Cinema: Abluka (Frenzy) and Sarmaşık (Ivy)

Prison and in more general terms imprisonment is one of the most interesting topics in cinema. To viewers, movies provide a gateway to a world which viewers cannot experience as an observer in life and this world creates images in societal imagination related to it. In fact, the topic of prison provides the film makers with an opportunity for multilayered expression and enables them to create various metaphors related to limitations on freedom. In addition, Turkish cinema has a unique and strong relationship with the image of prison. In this study, first of all Turkish cinema after 1980s and the topic of imprisonment will be evaluated, and then two important movies from 2015 -Abluka and Sarmaşık- will be analysed in terms of their approach to the topic of imprisonment. Upon analysis, it will be suggested that individuals turn to imagination, dreams and a kind of delusion to deal with the circumstances they face when their freedom has been taken away by people in power and that's why this method has been employed by film makers in today's cinema.
\end{abstract}

keywords: Turkish cinema, imprisonment, prison, Abluka (Frenzy), Sarmaşık (lvy) 


\section{Résumé}

\section{Représentations de l'emprisonnement dans le cinéma turc: Abluka (Frénésie) et Sarmaşık (Ivy)}

L'emprisonnement est l'un des sujets les plus intéressants du cinéma. Les films offrent une passerelle vers un monde inconnu où les spectateurs n'ont pas forcement liexpérience d'observateur dans la vie réelle. Le cinéma crée des images dans l'imaginaire sociale sur ce monde inconnu. En fait, le thème de la prison fournit aux cinéastes l'occasion pour l'expression multidimensionnelle et leur permet de créer diverses métaphores liées aux limitations de la liberté. En outre, le cinéma turc a une relation unique et forte avec l'image de la prison. Dans cette étude seront évalués tout d'abord, le cinéma turc depuis 1980 et le sujet de l'emprisonnement, puis deux films importants de 2015 -Abluka (Frénésie) et Sarmaşık (Ivy) - seront analysés en fonction de leur approche à la question de l'emprisonnement. En partant de cette analyse, il sera suggéré que les individus se tournent vers l'imagination, les rêves et vers une sorte d'illusion pour faire face aux circonstances auxquelles ils sont confrontés lorsque leur liberté est retirée par le pouvoir. C'est la raison pour laquelle cette méthode est employée par les cinéastes du cinéma d'aujourd'hui.

mots-clés: cinéma turc, prison, emprisonnement, Abluka (Frénésie), Sarmaşık (Ivy)

\section{Öz}

Hapishane ve daha genel anlamıla hapsedilmişlik sinemanın en çekici konularından biridir. Filmler izleyicilerine gerçek hayatta gözlemci olarak içine girmenin mümkün olmadığı bir dünyanın kapısını açar ve bu dünyaya dair toplumsal hayal gücünde imgeler yaratır. Diğer yandan hapishane konusu sinemacıya çok katmanlı bir ifade olanağı sağlar; toplumsal baskı ve özgürlüklerin kısıtlanmasına dair çeşitli metaforların yaratılmasına aracılık eder. Tüm bunlara ek olarak Türkiye Sineması'nın hapishane imgesiyle ilgili kendine has güçlü bir ilişkisi vardır. Bu çalışmada öncelikle 1980 sonrası Türkiye Sineması ve hapsedilmişlik konusu ile ilgili genel bir değerlendirme yapılacak, sonrasında 2015 yılının iki önemli filmi Abluka ve Sarmaşık'ta hapsedilmişlik konusunun ele alınış biçimi incelenecektir. Analizlerin sonucunda iktidar tarafından özgürlügü elinden alınmış bireylerin bununla başa çıkmak için hayallere, düşlere ve bir çeşit delilik haline sığındıkları ve bunun içinde bulunduğumuz dönemin sinema anlayışında da başvurulan bir yol olduğu iddia edilecektir.

anahtar kelimeler: Türkiye Sineması, hapishane, hapsedilmişlik, Abluka, Sarmaşık 


\section{Giriş}

Hapishane ve daha genel anlamıyla hapsedilmişlik tüm dünyada hem popüler hem de bağımsız sinemacıların sevdiği bir inceleme alanıdır. Sinema, izleyicisine gerçek hayatta gözlemci olarak içine girmenin mümkün olmadığı bir dünyanın kapısını açar ve bu dünyaya dair toplumsal hayal gücünde imgeler yaratır. Hapishane hakkındaki izlenimlerin birçoğu filmlerden kaynaklanır. Diğer yandan hapishane konusu sinemacıya çok katmanlı bir ifade olanağı sağlar; toplumsal baskı ve özgürlüklerin kısıtlanmasına dair çeşitli metaforların yaratılmasına aracılık eder. Bireyin iktidarın şiddetiyle karşılaşması, toplumdaki ve insan ilişkilerindeki güç çatışmaları, mekânsal olarak kısıtlanmış bireylerin çıktığı içsel yolculuklar bu filmlere toplumsal ve psikolojik derinlik katar. Tüm bunlara ek olarak Türkiye Sineması'nın hapishane imgesiyle ilgili kendine has güçlü bir ilişkisi vardır. Özellikle yakın geçmişteki tarihsel toplumsal olaylara bağlı olarak gelişen bu güçlü ilişki hapishanenin hem gerçek anlamda hem de sembolik olarak birçok farklı bağlamda temsilini beraberinde getirir. Yılmaz Güney ve Şerif Gören'in Yol'u (1981) ve yine Yılmaz Güney'in Fransa'da çektiği Duvar'ı (1983) Türkiye'deki insan hakları ihlallerini ve özgürlük mücadelelerini hapishane hikâyeleri üzerinden kurgular. Diğer yandan pek çok toplumsal ve siyasal olay hapishane olgusuyla ilişkili olarak ele alınır. Almanya'ya göçü ele alan birçok filmde göçmen kadının hapsedilişi ya doğrudan hapishane hikâyeleriyle ya da evlerin hapishaneye dönüştürülme hikâyeleriyle ortaya konur. 12 Eylül dönemiyle ilgili birçok film de bu dönemin açtığı yaraları ve bıraktığı izleri hapishane hikâyeleri aracılığıyla aktarır. Pek çok özgürlük ve eşitlik mücadelelerinin verilmeye devam edildiği günümüzde de bu imge etkin rolünü sürdürür.

Bu çalışmada 1980 sonrasındaki tarihsel süreçte Türkiye Sineması'nda hapishane ve hapsedilmişliğin çeşitli bağlamlardaki temsillerinin bir devamlılı̆ı olduğu fikrinden hareketle bu temsil biçimlerine dair genel bir değerlendirme yapıldıktan sonra konunun günümüz bağımsız sineması için de önemini koruduğuna dair iki örnek olan Abluka ve Sarmaşık filmleri incelenecektir. Hapishanenin mevcut kanunlara göre işlenen bir suçun cezasını çekmek üzere gidilen bir "cezaevi" olarak kullanılan düzanlamı dışında daha geniş çağrışımlarının ele alındığı Türkiye Sineması'nın konuya yaklaşımı daha genel bir ifade olan hapsedilmişlik çerçevesinde incelenecektir. Hapsedilmişlik kavramı ise cezalandırmak ya da baskı altında tutmak amacıyla bireylerin hayatının otoriter bir güç tarafından mekânsal olarak kısıtlanması anlamında kullanılacaktır. Ancak şüphesiz özgürlüğü kısıtlanmış bireylerin yaşadıkları baskılar sonucunda zihinsel ve düşünsel olarak da kısıtlanmış hissetmelerine bağlı olarak ortaya çıkan bunalımlar da konunun önemli bir boyutunu oluşturmaktadır.

Abluka ve Sarmaşık filmlerinin incelemesine geçmeden önce yapılan değerlendirmenin amacı hapishane ve hapsedilmişlik konusunun toplumsal ve siyasal boyutlarıyla sinemada ne denli geniş bir yer tuttuğunu ortaya koymaktır. Türkiye'nin yakın tarihiyle ilişkili olan hapishane ve hapsedilmişlik temsilleri 
günümüz sinemasında da farklı bağlamlarda ve biçimlerde önemini korumaktadır. Çalışmamız, Türkiye Sineması'nda önemli bir yeri bulunan hapsedilmişlik durumunun son dönem filmlerinde öne çıkan temsillerinin günümüzdeki hangi toplumsal olgularla ve ruh halleriyle ilişkilendirilebileceği sorusuna yanıt aramayı amaçlamaktadır. Incelenen iki filmin seçilme nedeni öncelikle konuyla ilişkilerinin isimlerine yansıyacak derecede açık ve doğrudan olmasıdır. Diğer yandan bu filmlerin ortak bir ruh halinden beslendiğine ve bu durumun biçimsel ve anlatısal olarak ortak bir sinema diline yol açtığına dair iddiamız bu iki filmi birlikte incelemeyi gerekli kılmaktadır. Yapılacak film çözümlemeleri biçimsel incelemeler barındırsa da ağılıklı olarak karakter incelemelerine, tematik ve söylemsel analizlere dayandırılacaktır.

\section{Sinejenik Bir Mekân: Hapishane}

Hapishanede geçen birçok filmin hem ticari hem de sinemasal alandaki başarısı, hapishanenin pek çok yönüyle sinejenik1 bir mekân oluşundan kaynaklanır. Tüm zamanların en iyi filmleri listelerinde yer alan Alkatraz Kuşçusu (John Frankenheimer, 1962), Kelebek (Franklin J. Schaffner, 1973), Kuzuların Sessizliği (Jonathan Demme, 1991), Esaretin Bedeli (Frank Darabont, 1994), Ölüm Yolunda (Tim Robbins, 1995), Yeşil Yol (Frank Darabont, 1999) gibi filmler popüler sinemanın konuya olan ilgisine dair akla gelen ilk örneklerdir. Hapishane filmleri izleyicilerine gerçek hayatta gözlemci olarak içine girmenin mümkün olmadığı bir dünyanın kapısını açar ve bu dünyaya dair imgeler yaratır. Konuya olan ilgi son yıllarda televizyon dizilerinde de sürer, Lost (ABC), Prison Break (Fox) gibi dizilerin küresel anlamdaki izleyici başarısı hapishane ve hapsedilmişlik anlatılarına olan merakın diğer bir göstergesidir.

Türkiye Sineması'nda ise hapishanede geçen popüler filmler ve diziler genelde masum bir mahkumun (kader mahkumunun) haksız yere düştüğü bu yeni dünyanın kurallarını keşfi, hapishanenin karizmatik şefine (dayısına) kendini kabul ettirip ondan öğrendikleriyle uğradığı haksızıkların hesabını sorması üzerine kuruludur. Bayrampaşa Ben Fazla Kalmayacağım (Hamdi Alkan, 2007), O Şimdi Mahkum (Abdullah Oğuz, 2004) gibi filmlerde veya Ezel, Parmaklıklar Ardında gibi yerli dizilerde buna benzer hikayeler işlenir.

Hapishane hikâyeleri bir yandan popüler anlatılara zengin bir malzeme kaynağı sunarken diğer yandan da sinemacılara çok katmanlı bir ifade olanağı sağlar; toplumsal baskı ve özgürlüklerin kısıtlanmasına dair çeşitli metaforların yaratılmasına aracılık eder. Bireyin iktidarın şiddetiyle karşılaşması, toplumdaki ve insan ilişkilerindeki güç çatışmaları, mekânsal olarak kısıtlanmış bireylerin çıktığı içsel yolculuklar bu filmlere toplumsal ve psikolojik derinlik katan öğelerdendir. Zaman-mekân ilişkisinin yeniden kurgulandığı, mekânın çok kısıtlı, zamanın ise

1 Nijat Özön (1981) Sinema ve Televizyon Terimleri Sözlügü'nde Fransızca "cinégénique" kavramını "filmegider" olarak Türkçeleştirmiştir. 
çok bol olduğu bu yeraltı dünyaları sinemacının da sinemasal zaman üzerine yeni yaklaşımlar geliştirmesine olanak sağlar. Birey, kapatıldığı kısıtlı mekânda zamanla ilişkisini yeniden düzenlerken, sinemacı da anlatısı için yeni bir zamanmekân tasarısına ihtiyaç duyar. Bu ihtiyaç ve sinemasal arayış yenilikçi anlatıları da beraberinde getirir. Örümcek Kadının Öpücügü (Hector Babenco, 1985), Açlık (Steve McQueen, 2008), Yeraltı Peygamberi (Jacques Audiard, 2009) hapishane anlatılarının sinema diline katkı sağlayacak zemini sunduğuna dair birkaç örnektir.

\section{Türkiye Sineması'nda Hapishane ve Hapsedilmişlik}

Hem büyük bütçeli popüler filmlerin hem de sinematografik açıdan güçlü bağımsız yapımların konusu olabilen hapishane ve hapsedilmişlik Türkiye Sineması'nda konunun sinemasal çekiciliğinin ötesinde daha özel bir yere sahiptir; çok geniş çağrışımlı bir sembol ve çok katmanlı bir anlatı aracı olmasının yanı sıra hapishane sinemanın Türkiye ile ilgili yarattığı en güçlü imgelerden biridir. Bu bağlamda akıllara hemen Midnight Express (1978, Alan Parker) filmi ve "Türkiye'nin zedelenen imajı" meselesi gelir kuşkusuz. Bununla birlikte Türkiye Sineması'na uluslararası tanınırlığı getiren filmlerde de farklı biçimlerde yeniden üretilir. Yılmaz Güney ve Şerif Gören'in Yol'u (1981) ve yine Yılmaz Güney'in Fransa'da çektiği Duvar'ı (1983) Türkiye'deki insan hakları ihlallerini ve özgürlük mücadelelerini hapishane hikâyeleri üzerinden kurgular. Yılmaz Güney'den itibaren, Yeni Türkiye Sineması olarak adlandırılan 2000'li yılların bağımsız sinemacılarını da kapsayan bir dönemdeki toplumsal ve kişisel ruh hallerini yansıtan filmlerin önemli bir bölümünde hapishane imgesinin yansımaları görülür, pek çok toplumsal ve siyasal olay hapishane olgusuyla ilişkili olarak ele alınır. Yakın geçmişimizde yaşanan askeri darbeler, özellikle 12 Eylül dönemindeki işkenceler ve baskılar birçok filme konu olur. Bu dönemin açtığı yaralar ve bıraktığı izler hapishane hikâyeleri aracılığıyla aktarıır. Yol (Yılmaz Güney, Şerif Gören, 1981), Ses (Zeki Ökten, 1986), Uçurtmayı Vurmasınlar (Tunç Başaran, 1989), Eve Dönüş (Ömer Uğur, 2006) bu dönemin siyasi mahkûmlarının gördüğü işkencelerin veya dönemin baskı ve paranoya ortamından nasibini alan "sade vatandaş"ın "sakıncalı" hale dönüşmesinin ele alındığı filmlerdir².

Diğer yandan 80'li yıllardan itibaren yoğunluk kazanan hak mücadeleleri, düşünce özgürlüğünün önündeki engeller, göçler ve sürgünler, ataerkil ve cinsiyetçi baskılar, çarpık kentleşme ve kentsel dönüşüm, terör korkusu, toplumsal güvensizlik ve paranoya beraberinde gerçek ve sembolik anlamda hapsedilme öykülerini getirir. Yalnızca hapishaneler değil, hapis-evler, hapisşehirler, hapis-hayatlar filmlere konu olur.

Öyle ki Amerikan filmlerinin hapisten kaçma mücadelesi veren kahramanIarının yerini sinemamızda -toplumsal baskıların günlük hayatı hapis hayatından daha çekilmez kılması nedeniyle- hapisten çıkmak istemeyen kahramanlar alır.

2 Konuyla ilgili bkz. Paça Cengiz (2016). 
Örneğin, 80ıli yıllarda Almanyaıya göçü konu alan filmlerin çoğunluğunda olduğu gibi Sahte Cennete Veda (Tevfik Başer, 1989) filminin başkahramanı Elif'in Almanya'daki hayatının da hapishaneden farkı yoktur. Kendisine zulmeden kocasını öldürür ve altı yı hapis cezası alır. Başta kendisini zorlayan koşullarına rağmen hapishane ona Almanca öğreneceği bir okul ve yeni arkadaşlar edineceği bir sosyal ortam sunar. Burası cezası bittiğinde onu bekleyen muhafazakâr hayatı ve hele de kan davalılarını düşününce çok daha yaşanası bir yerdir. Avrupa ülkelerine göç etmiş göçmen kadınların ev-hapishanelerdeki tutsaklı̆ından bahsederken 40 m2 Almanya (Tevfik Başer, 1986,) Şirin'in Dügünü (Helma Sanders-Brahms, 1976), Yasemin (Hark Bohm, 1988) gibi filmleri de anmak gerekir. Bu filmlerin tamamında Anadolu'dan Avrupa ülkelerine göç etmiş kadınların ataerkil düzenin sürdürebilmesi uğruna hapsedilişleri ele alınır. Bu hapsedilmişlik öykülerinde hapis evlerde yaşanan şimdiki zamanın acısını dindirmek için tek çare bellek yoluyla geçmişe, anılara ve çocukluk yıllarına gitmek ve memleket hayallerine dalmaktır.

Göçmen kadınların bu türden temsilleri özellikle Avrupalı yapımcılar ve izleyiciler için Türkiye ve Türkiye Sineması deyince akla gelen hapishane imgesiyle de bütünleşir. Türkiyeli kadınların hapsedilmişlikleri üzerine ortaya konan temsil biçimleri 90'lı yıllarda ve günümüzde de farklı bağlamlarda varlığını sürdürür. Benzer bir biçimde Sinan Çetin'in 1993 yapımı Berlin in Berlin'i Almanya'da yaşayan muhafazakâr Türk ailesinin gelini Dilber'in aile baskısından, yanlışıkı inşaat işçisi olan kocasının ölümüne yol açan Alman mühendis Thomas sayesinde kurtuluşunu anlatır. Anlatısını oto-oryantalist bir bakışa dayandıran film sadece kapatılmış, pasif ve mağdur bir kadın figürü yaratmakla kalmaz, kurtuluşun da ancak batılı bir erkek eliyle mümkün olabileceği savını ortaya koyar.

Günümüze geldiğimizde ise Fransız-Türk yönetmen Deniz Gamze Ergüven'in Mustang'inde hapsedilmiş kadınlar ve onlara reva görülen bir hapishane-ev çıkar karşımıza. Film boyunca Karadeniz'in uçsuz bucaksız ormanları içindeki ferah feza, bahçeli, cumbalı evin, ataerkil-ahlakçı ve riyakâr-tecavüzcü aile reisi ve ona yardımcı olan kadınlar tarafından, kızlarının namusunu korumak adına fiziksel ve sembolik olarak bir hapishaneye dönüştürülmesi anlatılır.

Bu filmler Türk toplumundaki ataerkil ve kadına karşı ayııımcı ve baskıcı tutuma eleştirel bir bakış getirse de aynı zamanda sürekli tekrar eden pasif, mağdur, acı çeken ve buna boyun eğen kadın temsilleri ortaya koyduğu için yakın dönem sinema incelemelerinde tartışma konusu olmuştur.

80'li yıllarda çekilen toplumsal gerçekçi filmlerin biraz da görev bilinciyle göçmen kadınları kurtarılmayı bekleyen mağdurlara indirgeyen bu temsilleri ve bunların Avrupa'da yaşayan Türkiyeli göçmen kadınların farklı kökenlere, ailelere ve sosyal çevrelere mensup oluşlarına göre çeşitlilik gösteren hayatlarını ve uyum süreçlerini yansıtmakta yetersiz kalışı Deniz Göktürk, Hamid Naficy, Fischer ve McGowan gibi sinema araştırmacıları tarafından eleştirilir (Fischer, McGowan, 
1996, s.12; Naficy, 1994, s.18; Göktürk, 2000, s. 69). Avrupa ülkelerindeki Türkiye kökenli göçmen kadınların içine hapsedildikleri duvarları sorguladıkları ve onlara karşı geldikleri film Fatih Akın'ın Duvara Karşı'sı olur. Ancak bu kez de görünmez duvarlar vardır aşılması gereken, içselleştirilmiş toplumsal normlar, kültürel sınırlar gibi konular tartışılmaya açılır Fatih Akın'ın filmlerinde.

\section{Bir Açıkhava Hapishanesi Olarak Türkiye}

Fatih Akın'a ve birçok yakın dönem sinemacıya ilham kaynağı olmaya devam eden Yılmaz Güney'in son dönem filmlerinden Yol (1981) Türkiye Sineması'nda hapishanenin anahtar sembollerden biri haline gelişinde bir dönüm noktasıdır. Hemen ardından siyasi sığınmacı olarak Fransa'da bulunduğu dönemde çektiği son filmi Duvar (1983) da çocuklar koğuşunda çıkan ve tüm cezaevine yayılan bir isyanı konu alır. Sinemada aktif olduğu 20 yılın 12 yılını hapiste, iki yııını askerde, üç yılını da sürgünde geçiren Güney, sinema kariyerinin ve hayatının son döneminde yaptığı bu filmlerde özgürlük ve tutsaklıkla ilgili hayatı boyunca deneyimlediği çelişkileri ortaya koyar (Naficy, 2001, s. 182). Yılmaz Güney için hapishane hem düz anlamda hem alegorik olarak bir anlatı aracıdır. Üzerine çokça çalışılan ve Türkiye Sineması'nın modernleşmesindeki önemi de sıkça dile getirilen Yol, Ulus Baker'in belirttiği gibi "bir dizi öyküyü tek bir montaj toplamında birleştirerek, hapishaneyle "dışarısının" tek ve aynı yer olduklarını, aynı katlanılamaz kapatmanın, dolayısıyla her yerde işleyen bir genel politik gerçekliğin ifadesi olduklarını gösterir bize" (Baker'den aktaran Arslan, Göral, 2016). Yılmaz Güney, Şerif Gören'in de büyük katkılarıyla, 12 Eylül döneminin bütün bir ülkeyi bir açık hava hapishanesine dönüştürüşünün izlerini sürer Yol'da. Güney'in döneminin politik atmosferini cezaevinden bayram iznine çıkan beş mahkûmun eve dönüş hikâyeleri aracılığıyla yansıttığı Yol'da en olgun haliyle ortaya koyduğu modern politik tavır ${ }^{3}$ kişisel ve özel olandan hareketle toplumsal ve politik olan hakkında samimi ve gerçekçi tespitlerin yapılmasını mümkün kılar. Umut Tümay Arslan ve Özgür Sevgi Göral'ın (2016) Baker'den esinlenerek söylediği gibi:

\footnotetext{
"Yılmaz Güney sineması modern sinemaya özgü bir politika ve iktidar tasavvuruna sahiptir -politik aygıtlarda görülmeyen bir yığın mikropolitik unsur, boyun eğenlerin dayanakları ve çıkarları, gündelik hayatını düzenleyemeyenlerin dünyayı kurtarmaya çalışmasının absürdlüğü, hakkında bilinçleneceğimiz politik ve sosyal bütünlükten çok en mahrem, en özel meselelerden türetilen katlanılamaz bir gerçeklik. Bildik-tanıdık politik sinemadan uzak modern sinemaya yakın bu sinema "modernliğin siyasal alanının bir özelliğini keşfine dayanır: Hiçbir şey politikadan uzakta değildir [...]".
}

3 Yılmaz Güney yine otobiyografik özellikler taşıyan Umut'taki politik ve yenilikçi tavrını ilk kez Yol'da böylesine açıkça ortaya koyar. 1972'de hapse girene kadar çektiği birçok film her ne kadar sınıfsal farklılıkların yarattığı haksızlıkları ve eşitsizlikleri yansıtsa ve Güney'in siyasal tavrını ortaya koysa da (1971'de spagetti western turu macera filmi Vurguncular'da kahramanların Nazım Hikmet şiirleri okuması, Maocu gençlere yardım etmeleri, vb.) genel izleyiciye hitap eden Yeşilçam filmleridir. Senaryosunu yazdığı ancak hapiste olduğu için Yol gibi başka bir yönetmen, Zeki Ökten tarafından çekilen Sürü (1978) ve Düşman (1979) ise Umut'takine benzer bir politik tavrı ortaya koyar. 
Günümüz sinemasının konuyla olan ilişkisi bağlamında daha yakından incelemek istediğimiz Abluka ve Sarmaşık da bu fikri destekler nitelikli hikâye örgüleriyle, tamamen bireysel olandan yola çıkıp içinde bulunduğumuz dönemin ruh haline, politik durumuna ve toplumun önemli bir kısmında etkili olan özgürlüklerin kısıtlanmışlığı duygusuna işaret etmeleriyle çalışmamıza konu olacaktır.

\section{Hapsedilmişlik ve Delilik}

Her ikisi de yönetmenlerinin ikinci uzun metraj filmi olan Ablukave Sarmaşık kullanılan sinema dili açısından birbirinden oldukça farklı olsa da hapsedilmişliği ele alma bakımından birçok ortak noktaya sahiptir. Hapsedilmişlik karşısında üretilmeye çalışılan çıkış yolları da benzerlikler taşır.

2015 yılı yapımı olan Abluka ve Sarmaşık ulusal festivallerde pek çok ödül kazandıkları gibi (Altın Portakal, Siyad), uluslararası festivallerde de övgüyle karşılanmışlardır" . Senaristi ve yönetmeni Emin Alper Tarafından "politik-psikolojik bir gerilim" (Çiftçi, Göl, 2015, s. 22-23) olarak nitelenen Abluka Türkiye'nin politik durumuna göndermeler yapan anlatısında distopik öğeler barındııı. Film yirmi yıl hapis yatan Kadir'in, cezasının bitmesine iki yıl kala, çöplerde patlayıcı madde yapımında kullanılan maddeleri tespit edip polis şeflerine inbar etmek şartıyla salıverilmesiyle başlar. Hapisten çıkan Kadir, -Yol filminde bayram iznine çıkan kahramanlara benzer bir biçimde- dışarıyı tanınmaz halde bulur ${ }^{5}$. Kadir'in küçük kardeşi Ahmet'in yaşadığı yoksul mahalle abluka altındadır ve buraya ancak polis kontrol noktasındaki aramalardan sonra giriş yapılabilmektedir. Kadir 20 yıldır görmediği Ahmet'in yakınlarında, onun arkadaşları olan Ali ve Meral'in evini tutar. Kısa zamanda Ahmet'in karısı tarafından terk edildiğini ve depresif bir ruh hali içinde olduğunu fark eder ve kendisinin de ilgisini çeken Meral'le bir ilişkisi olduğundan şüphelenir. Belediyenin köpek itlaf ekibinde çalışan ve köpekleri vurarak hayatını kazanan Ahmet ise intiharın eşiğindedir ve abisinin yakınlaşma çabalarına karşılık vermek istemez. İki kardeş arasındaki iletişimsizlik, artan patlamalarla şehirde tırmanan gerilim, şehirde bombalı saldırılar düzenleyen örgütün mahallede barınması ve kilit adamlarından birinin Kadir ve Ahmet'in bir süredir kayıp olan diğer kardeşleri Veli olması şüphesi filmin gerilimini giderek arttırır. Filmin sonlarına doğru bir yandan Ahmet'in yaraladığı bir köpeği tedavi ederek evinde saklamaya başlaması ve kendini eve hapsetmesi, diğer yandan

4 Abluka; Venedik Film Festivali'nde jüri özel ödülü, Asya Pasifik Film Ödülleri'nde jüri büyük ödülü ve Siyad'da en iyi film, en iyi yönetmen, en iyi senaryo, en iyi kurgu ödüllerini; Sarmaşık ise East End Film Festivali'nde en iyi film ve Antalya Film Festivali'nde en iyi film, en iyi yönetmen, en iyi senaryo, en iyi erkek oyuncu ödüllerini almıştır. http://www.imdb.com/title/tt4309356/ awards?ref_=tt_awd; http://www.imdb.com/title/tt4895740/awards?ref_=tt_awd

5 Kadir bu durumu "Allah allah memleket bir acayip olmuş ya.", "Değişmiş tabi canım, herkes bir deliklere girmiş, acayip acayip işler yani", "20 sene önce böyle değildi tabi, biz ekmek derdindeydik, şimdi millet can derdinde. Nasıl kurtulacak bu beladan bu millet bilemedim valla" gibi sözlerle ifade eder. 
Kadir'in Ahmet'in yarattığı şüpheli durumun, onun evde polis tarafından örgüt üyeliğinden aranan Meral'i saklamasından kaynaklandığını düşünmesinden doğan paranoya iki kardeşi, gerçeklikle bağlarını tamamen kopardıkları bir delilik haline sürükler. Öyle ki bu hastalıklı paranoyak hal Kadir'i Ahmet'i ihbar etmeye, Ahmet'i de polise ateş açmaya sürükleyecektir. Final sekansında kardeşi ölen Kadir onun evinde örgüt üyelerince yakalanır ve kapanış sahnesinde diz çökerek infazını bekler halde kalır.

Tolga Karaçelik'in yazıp yönettiği Sarmaşık, bir uluslararası yük gemisinde çalışan beş gemici ve bir kaptanın armatör şirketin iflası sonucu, limana yanaşamadıkları için gemide belirsiz bir süre için nöbetçi kalmaları ve belirsizliğin uzamasıyla gemideki gönüllü kalışın bir çeşit esarete dönüşmesinin yarattığı gerilim ekseninde ilerler. Filmin açılış sekansındaki planlarda tüm karakterler, arka arkaya gemiye gelmeden önceki hayatlarında görünürler. Brechtien bir biçimde karakterlerin izleyiciyle göz teması kurduğu bu kısa planlar gemicilerin geçmişiyle ilgili, filmde yer alan yegâne görüntülerdir. Bunun dışında tüm film gemide geçer. Gemi ekibine yeni katılan Cenk ve Alper gemide çalışmayı başlarını beladan kurtarmak ve eski hayatlarından bir süre uzaklaşmak için tercih etmişler ve işi öğrenmekten ziyade kaytarmanın yollarına bakmaya başlamışlardır. Tanıştıkları ilk günden itibaren birlikte ot çekmeleri ve gemide eğlenmenin yolunu bulmaları hemen arkadaş olmalarını sağlar. Ekmeğinin derdinde olan "roman" Nadir ve "dindar" İsmail ise kaptan Beybaba'ya hürmette kusur etmeden onun takdirini kazanmaya çalışmaktadırlar. Gerçek ismini hiç öğrenmediğimiz Kürt ise tümünden uzak durur ve neredeyse hiç konuşmadan işine bakar. Geminin Afar Limanı'na yanaşmaya hazırlandığı sırada armatörün iflasını açıklamasıyla bu beş gemici, geminin limana yanaşma işlemleri tamamlanana kadar Beybaba ile birlikte gemide kalmaya gönüllü olurlar. Gerek yapacak daha iyi bir işleri olmadığı eski hayatlarına bu kadar çabuk dönmek istemediklerinden ve demir attıkları için yan gelip yatabileceklerini düşündüklerinden (Cenk, Alper), gerekse Beybaba'ya hürmetlerinden ve paraya ihtiyaçları olduğundan (İsmail, Nadir) gemide kalmak isteyen gönüllülerin hayatları sürecin uzamasıyla çekilmez bir hal alır. Beybaba'nın otoritesi ve despotluğuyla ezdiği ve zamanın akmadığı bir gemide demirli kalan gemiciler giderek birbirlerine de düşmanlık beslemeye başlar ve özellikle Cenk'in Beybaba'ya ve ona yakın duran İsmail'e olan öfkesi esrar stokunun bitmesiyle iyice tırmanır. Abluka'da olduğu gibi bir paranoya ve delilik hali gemiyi ele geçirir. Filmin sonuna doğru İsmail'i yaralayıp gemide bulduğu tüm uyuşturucuları içen Cenk'in gemisi sarmaşıkların bir yaratık gibi her yeri kapladığı ve salyangozların işgal ettiği fantastik bir dünyadır artık. Film, tüm mürettebatın ayılarak güvertede bir araya geldiği filmin kapanış sahnesiyle ve zayıf da olsa Beybaba'ya karşı birleşecekleri imasıyla son bulur.

Filmlerin isimleri daha baştan bir kapatılma ve kaplanmaya, etrafı sarılarak hareketsiz bırakılmaya işaret eder. Abluka'da "abluka" düz anlamıyla da mevcuttur ancak hikâye ilerledikçe ortaya çıkan bir çeşit zihinsel abluka ve akıl tutulması, kavramın alegorik anlamlarını da filme eklemler. Filmin İngilizce 
ve Fransızca'daki isimlerinin (Frenzy/Frénésie) "aklını kaçırma" anlamına gelmesine karşın Türkçe isminin Abluka olması konunun Türkiye'nin sosyopolitik koşullarıyla ve toplumsal bellekteki izleriyle ilişkili kendine has yerine işaret eder. Filmin yönetmeni senaryosu için siyasal çatışmaların ve baskıların, kontrollerin, toplumsal güvensizlik ve şiddet olaylarının tırmandığı 1970'ler, 12 Eylül ve 90'lı yılları esin kaynağı olarak ele aldığı halde filmin gösterime girdiği dönemde bunlara Suruç ve Ankara katliamlarıyla yenilerinin eklendiğinden söz eder (Par, 2015). Emin Alper bu olaylarla birlikte filminin beklenmedik bir bağlama oturduğuna ve bu saldırıları takiben Güneydoğu illerinde uygulanan sokağa çıkma yasakları ve ablukaların yaşadığımı ülkeyi giderek filmdeki hayali ülkeye benzer hale getirdiğine dikkat çeker (Çiftçi, Göl, 2015, s. 23). Tüm bunlar göz önünde bulundurulduğunda filmin isminin işaret ettiği otoriterlik ve baskı Türkiye'ye özgü bir tarihsel-politik gerçeklikle ilişkilidir.

Sarmaşık'ta "sarmaşık" filmin başkarakterlerinin tanıtıldığı açılış sekansında bir mezarlıkta, terkedilmiş mezar taşlarını kaplamış bir halde gösterilir izleyiciye. Buradan hareketle o da bir anlamda gemi mürettebatının bir parçasıdır. Bu ilk tanışmada sarmaşık doğanın ahengine katkıda bulunan simbiyotik bir bitkiden çok durdurulmadığı takdirde her yeri ve her şeyi saracak ve kaplayacak bir işgalciyi çağrıştırır ve ölümle ilişkilendirilir. Filmin sonlarına doğru film kahramanlarının arasındaki çatışmanın tırmanmasıyla ve Cenk'in İsmail'i yaralaması ve Nadir'in bileklerini kesmesiyle kan yerine çıkan ve yayılan sarmaşık fantastik ve alegorik bir figüre dönüşür. Şiddetten beslenen karanlık bir yaratık gibi tüm gemiyi kaplar. Sonuçta her iki filmin de anahtar sembolü tutsaklık çağrışımını zihinlerde canlandırır.

Abluka ve Sarmaşık birbirinden farklı bir zamansal kurguya sahiptir. Sarmaşık'ta Tolga Karaçelik doğrusal ilerleyen bir kurgusal yapıyı tercih ederken, Emin Alper Abluka için sıçramalı bir kurgu kullanır. Zamanın doğrusal ilerlemediği bu kurgusal yapıda geriye doğru zaman atlamalarıyla olay akışı sekteye uğratılır. Yönetmenin tabiriyle, zamandaki bu geriye atmalar filmin ilerlemesine de mani olarak izleyicide de bir ablukaya alınma duygusu yaratmayı amaçlar6. Aynı zamanda Kadir ve Ahmet'in bakış açılarını ayrı ayrı yansıtan bu kurgusal tercih sübjektif bir zaman tasavvuruna dayalıdır. Zamansal akıştaki kurgusal yaklaşım farkına rağmen her iki film de gerçekdışıyla gerçeğin iç içe geçmiş bir halde sunulduğu bir anlatı yapısına sahiptir. Filmleri birbirine en çok yakınlaştıran nokta da her ikisinin de ortalarından itibaren yükselişe geçen paranoya ve gerçekle bağların zayıfladığı bir çeşit delilik hali olur. Özellikle sona yaklaştıkça gerçek ve hayalin iç içe geçmesinden dolayı film anlatısı da karmaşıklaşır ve izleyicilerine takibi zor bir anlatısal deneyim sunar. Hem Abluka' da (otoriter bir baskı rejimi ve polis devleti tarafından) hem de Sarmaşık'ta (Beybaba tarafından) fiziksel ve düşünsel olarak baskı altına alınan ve kısıtlanan kahramanların hareket şansı bulamadıkları bir şimdiye mahkum edilmişlikten kaçış çabaları ele alınır. Sarmaşık'ta Afar Limanı

6 TFAYY Konferansı, Emin Alper'le Söyleşi, 7 Mayıs 2016, Kadir Has Üniversitesi 
açıklarında demir atılmasıyla birlikte hem geminin ilerlemesi hem de zamanın akışı durur. Zamanın kendisi Beybaba tarafından tutsak edilmiştir, bir tek onun kamarasında duyulan kuvvetli saat tiktakları ve sürekli elinde kurcalayıp durduğu, tamir etmeye çalıştığı kol saati zamanın onun tahakkümünde olduğunun altını çizer. Filmin sonlarına doğru Cenk, Alper ve Nadir'in itaat etmeyi bırakıp isyan ederek Beybaba'nın kamarasına girerek onun elinden kurtarmaya çalıştıkları asıl tutsak, zamanın kendisidir. Bunu başaramadıklarında işler çı̆̆ııından çıkar. Paranoya ve şüphe artar, İsmail ve Nadir Cenk'in Kürt'ü öldürdüğüne ve Kürt'ün hayaletinin gemide gezdiğine inanmaya başlar, Cenk kendisine küfreden ve Beybaba'nın muhbiri olan İsmail'i yok ederek Beybaba'ya yapamadıklarının da acısı çıkarmaya çalışır.

Sarmaşık'taki geminin mürettebatı toplumun alt sınıflarından gelen ve çeşitli açılardan tutunamayan tiplerdir. Cenk gemiden önceki hayatında yoksul mahallerde yaşayan ve kaçak elektrik kullanan insanları elektrik kurumu görevlisiyim diyerek dolandırarak geçinir. Alper ve Kürt taksi şoförlüğü ve "bodyguard" lık gibi işler yaparken görünür açlış sekansında. Yine aynı sekansta Nadir Sulukule'deki evinde televizyon izlerken görünür ve muhtemelen gemiye işsizlikten gelmiştir. Camide namaz kılarken görünen İsmail gemide yaptığı telefon konuşmasında borçlarını kapatmaya çalıştığından bahseder. Gemideki önce gönüllü sonra zorunlu tutsaklığın sonucunda deliliğin eşiğine gelen tüm bu karakterler Abluka'nın karakterleri gibi şehrin dışına doğru püskürtmekten kaçınmayacağı alt sınıf mensuplarıdırlar. Sarmaşık'ın gemisi Foucault'nun Deliliğin Tarihi (1995) eserinde bahsettiği “Deliler Gemisi'ni akıllara getirir. Foucault, XV. Yüzyıl Avrupası'nda delilerin gemilere bindirilerek yaşadıkları yerlerden uzaklaştııımasının birçok edebi eserde yer aldığından ve bunun gerçekteki karşıı̆ından bahseder. "Rönesansın imgesel manzarası içinde yeni bir cisim ortaya çıkmıştır; kısa bir süre sonra ayrıcalıklı bir yere sahip olacaktır: bu Renenya'nın sakin nehirleri ve Flaman kanalları boyunca dolaşan garip bir serseri tekne olan Deliler Gemisi'dir." (Foucault, 1995, s. 31) Şöyle devam eder Foucault:

Kaçıklardan meydana gelen yüklerini bir kentten diğerine taşıyan bu gemiler var olmuşlardır. Deliler o tarihlerde kolaylıkla gezgin bir yaşama sahip olmaktaydılar. Kentler onları sınırlarının dışına istekle atıyorlardı, bu gibiler uzak kırlara kovalanıyorlar veyahut bir tüccar veya hacı grubuna emanet ediliyorlardı. [...] Deliler çoğu zaman nehir gemilerine emanet edilmekteydiler (s. 32). Rönesansın başlangıç döneminin tümü boyunca hayallere musallat olan bu deli gemilerinin, hacı gemileri, akıllarını arayan meczupların çok simgesel tekneleri olmuş olmaları mümkündür" (s. 34) [...] Deliyi gemicilere teslim etmek, onun kent içindeki belirsiz dolaşmalarından kesinlikle kurtulmak, onun uzağa gideceğinden emin olmak, onu kendi yolculuğunun esiri kılmak demektir. (s. 36)

Sarmaşık'ın gemisinde kendi yolculuğunun esiri olmayı kaldıramayan kahramanlar tam da bu yüzden deliliğe sürüklenir. Ancak yine Foucault'nun dediği gibi "Deliliğin herkesi içinde kaybolunan bir körleşmeye sürüklemesine rağmen, deli bunun tersine herkese kendi gerçeğini hatırlatmaktadır." (s. 40). 
Abluka'da Ahmet, Sarmaşık'taki Nadir gibi filmin başından itibaren intiharın eşiğinde bir ruh haline sahiptir. Korku, baskı ve paranoyanın insanları kendi dünyalarında tek başına bıraktığı karanlık ve distopik dünyadan kaçmaya ve kurtulmaya çalışmaktadır. Insanlıktan uzak despot amirlerinin sürekli aşağıladığı ve ezdiği genç adam işi gereği öldürmeye çalıştığı ${ }^{7}$ ama sonra yaralı bir halde bularak evine aldığı ve giderek can yoldaşı yaptığı "Coni" ile birlikte eve kapandığı süreçte dış gerçeklikten kopma çabasını sinir bozucu bir şekilde çalan alarmıyla kendisine kopmaya çalıştığı dünyayı anımsatan saati parçalayarak ortaya koyar. Bir yandan da bu süreçte evinin iç duvarlarından birini yıkmaya başlar. Film boyunca tam olarak nasıl bir amaç için yıkıldığı anlaşılmayan duvarın küçük aletlerle azar azar gerçekleştirilen yıkım operasyonu tam da bir hapishaneden kaçış çabasını andırır. Ancak duvardaki delik dışarıya değil bir iç dünyaya açıır.

İki filmde de zamanın acımasız iktidar güçleri tarafından tahakküm altına alınması ve akışının durdurulması kahramanların içinden çıkamadıkları varoluşsal bir bunalıma sürüklenmesine yol açar. Şimdiye hapsedilmiş birey için içinde bulunduğu andan kurtulmanın iki yolu vardır, biri bellek yoluyla geçmişe sığınmak diğeri de düş ve hayal âlemine dalmak. Yukarıda bahsi geçen 80'lerin hapsedilen göçmen kadınları bu ruh halinden kaçışı anavatanda geçen anılarında ararlar. Burada ise hapsedilmişlikten kaçış için başka bir yol denenir: bilinç dışı ve hayal. Dışsal zamanın bulanıklaştığı, içsel ve öznel bir zamanın hüküm sürmeye başladığı film anlatısı bireysel ve ruhsal yolculuğa doğru evrilir.

\section{Hapishaneden Kaçış Yolu Olarak Hayal ve Düş}

Her iki filmde de film anlatısının önemli bir parçası olan rüyalar, modern edebiyattaki kullanımına benzer bir biçimde 8 "içinde bulunduğumuz zamanın dışında bir zamana sahiptir. Dolayısıyla başka bir gerçekliği vardır. Rüyalar kendini zamanına ve dış gerçekliğe ait hissetmeyen kahramanlarının kaçış noktası, kendilerini yeniden kurdukları bir ikinci evren olarak kullanılır" (Bayrak Akyıldız, 2009, s. 143). Bunun yanında rüyalar, pişmanlıklar ve korkularla yüzleşilen ikinci

7 Ahmet'in Belediye adına yürüttüğü bu hayali mesleği akıllara Serge Avedikian'ın Hayırsız Ada (2010) filmini getirir. Altın Palmiye ödüllü bu kısa film II. Meşrutiyet Dönemi'nin batılılaşma hareketleri sırasında iç işleri bakanı Talat Paşa tarafından verilen bir emirle İstanbul'un köpeklerinin toplatılarak Sivriada'ya sürgün edilmesini ve birbirini parçalayarak yok olmaya terkedilmesini konu edinir.

8 Gerek Abluka'nın yönetmeni Emin Alper gerekse Sarmaşık'ın yönetmeni Tolga Karaçelik filmleri için en önemli esin kaynakları arasında modern edebiyatı sayarlar. Sarmaşık Samuel Taylor Coleridge, Herman Melville ve Joseph Conrad'a "Beni çıkartııları tüm seferler adına" sözlerinin yer aldığı bir ithafla başlar. Edebiyat tutkusunu "edebiyat beni sinemadan daha fazla heyecanlandırıyor" (Edener 2015, s. 45) şeklinde ifade eden Karaçelik filminde için roman bölümlendirmesi biçiminde bir bölümlendirme kullanır. Her bölümden önce roma rakamıyla bir bölüm numarası ve bir edebi alıntı yer alır. Emin Alper de özellikle otorite figürü polis şefi Vahap ve Hamza'nın Kadir üzerinde tahakküm kurmaya çalıştıkları ve aynı zamanda kendi bayağıııkları ve acımasızlıklarını ortaya koydukları rakı masası sahnesi için Kafka ve Dostoyevski'den ilham aldığını belirtir. (Çiftçi, Göl 2015, s. 23) Tüm bu esinlenmeler ve postmodern alıntılar yönetmenlerin karakterlerine dair ruhsal tahliller ortaya koyma çabalarının bir göstergesidir. 
bir gerçeklik alanı olarak da karşımıza çıkar. "Modern yapıtlarda rüya, yalnızca eserin merkezine aldığı insanı, bütün derinliğiyle kavramanın bir yolu olarak değil, yeniden tanımlanan zaman ve mekân kavramlarının da, kişiye özgü şekilleriyle tezahür ettiği bir boyut olarak da önem taşır. Kırılıp bükülen, farklı dilimleri yan yana gelen zaman ve mekânıyla, gerçekliği, ne kronolojik ne de mantıksal dizilimle uyumlu olmak zorunda olan olay akışıyla rüyalar" (s. 143), modern sanatçılara yeni bir kurgu anlayışı için de esin kaynağı olmuştur. Bu esin kaynağından hareketle Sarmaşık'ta, hapsedilmişliğin ve baskının dozunun arttığı, zamanın Beybaba tarafından tahakküm altına alındığı gemide etrafı kaplayan sarmaşıklar ve ağır hareketlerle salınan salyangozlarla düşsel bir zamanın yaşandığı fantastik bir mekâna dönüşür. Zamanın hareketsizliği durumunda hareketi düş ve hayal sağlar. Abluka'da da hem Ahmet'in katlettiği köpeklerin üzerine geldiği ve koşarak yanından uzaklaştıkları hem de Meral'in polis baskınından kaçarak sığındığı kümesten Kadir tarafından kurtarıldığı sahnelerde ve özellikle de filmin son sahnesinde Kadir'in polis baskınında öldürülen Ahmet'in evine gelerek örgüte teslim olduğu sahnede tamamen düşsel bir gerçeklik söz konusudur.

Yapıtlarında düş ile gerçeği iç içe ele alan Tanpınar'da olduğu gibi maddeden ziyade ruh olan dram kahramanları (Tanpınar, 1969, s. 30) için uyanık hayatla rüyanın bu iç içe geçmişliği bize aynı zamanda Alman Dışavurumculuğu'nun biçimsel ve anlatısal etkilerini hatırlatır. Aslı Daldal'ın belirttiği üzere dışavurumculuktaki gerçeklikten kopmuş, bozulmuş bir görsellik "kabuğuna çekilmiş sıradan insanın kendi dünyasındaki kıstırımış, kapatılmış benlik hapishanesinin resmedilmesi idi" (2016, s. 92). Birinci Dünya Savaşı sonrası Alman toplumunun yaşadığı büyük yıkımın sonucunda ortaya çıkan bu akım bir kabuğa çekilme ruh halinden kaynaklanır ve bu durum filmlere bilinçdışı yaşantılar, içsel yolculuklar, kâbuslar, fanteziler, delilik hikâyeleri, şiddet ve paranoya temsilleri olarak yansır. Doktor Caligari'nin Muayenehanesi filminde doruğa çıkan dışavurumcu estetik deforme edilmiş bir dışsal gerçekliğin yansımalarıyla biçimlenir (Kuhn, Knight, 2009, s. 210). Özellikle incelediğimiz filmlerde de yer yer etkili olan karanlık atmosfer ve sert ışık-gölge oyunları sıradan insanın içindeki karanlığı görünür hale getirmek için dışavurumcu sanatçılar tarafından tasarlanan en etkili araçlardır. Abluka'da daha belirgin olan Dışavurumculuk "insanların etraflarında nefes alan" ve onların "neredeyse her şeyden şüphe duymaya başladığı tekinsiz bir atmosfer"i (Çiftçi, Göl, 2015, s. 21) yaratmak için kullanılır. Ahmet'in başa çıkmaya çalıştığı tam da Daldal'ın sözünü ettiği bir benlik hapishanesidir. Dışavurumculuk'tan etkilenen bir başka film türü olan film noir ${ }^{9}$ da Abluka'nın esin kaynaklarındandır. Özellikle Meral karakterinin femme fatal'e yakın duruşu, filmin genelindeki şüphe ve gerilim Abluka'yı film noir'a yakınlaştırır. Sarmaşık'ta da zaten çok iri bir cüsseye sahip Kürt'ün gemide dolaşan dev gölgesi ve yine geminin ambarında İsmail'in Kürt'ü aradığı sahnede ışık gölge ile yaratılan atmosfer bu filmin de dışavurumcu estetiğe yakın durduğu öğelerdir.

9 Konuyla ilgili bkz. Duncan, 2006; Silver, Ward 1992. 
Sarmaşık ve Abluka'yı dışavurumculuğa en çok yaklaştıran nokta ise estetik bir biçimsellikten ziyade genel tonda etkisini hissettiren baskıcı bir otoritenin yıkıcı etkilerinin hissedildiği bir dışsal gerçeklik tasviri ve bundan kopuş çabasıdır. Son birkaç yıldır Gezi sürecini de kapsayan dönemde Türkiye'nin içinde bulunduğu siyasal gerilim, Güneydoğu'daki çatışmaların şiddetini artırması, hak ihlallerine karşı yapılan toplumsal eylem ve gösterilerdeki polis şiddeti, zorunlu göçler, büyük şehirlerde artan terör saldırıları ve bunların sonucunda artan korku, panik ve paranoya, şehirlerin çehresini hızlı bir biçimde değiştiren, aynı zamanda şehrin ve şehrin sakinlerinin geçmişiyle bağlarının kopması anlamına gelebilen, düşük gelir grubuna mensup kişileri şehrin dışındaki toplu konutlarda (TOKi'lerde) yaşamaya mecbur bırakan kentsel dönüşüm sonucu ortaya çıkan karamsar ruh halinin bu dönemin filmlerine yansıması kaçınılmazdır ${ }^{10}$. Krakauer'in ve Sorlin'in belirttiği gibi filmler belirli bir ülkenin belirli bir döneminin ruh halinin ürünleridir (Krakauer'den aktaran Sorlin, 1977, p. 47). Filmlerin içinden çıtığı toplumun o dönemdeki intiyaçlarını, eğilimlerini, ülkenin içinde bulunduğu durumu ve toplumun ruh halini yansıtır. Abluka ve Sarmaşık'taki ruh halinin başka bir dönemde başka bir yıkımdan doğmuş olan dışavurumculuğu çağrıştırması çok şaşırtıcı değildir. Öyle ki özellikle İstanbul'da kentsel dönüşüm olarak sunulan ve hem kent sakinleri hem de tarihçiler, mimarlar, şehir plancıları, sosyologlar tarafından çokça tartışılan ve eleştirilen yıkımlar ve yapılan yeni binalar her iki filmde de anlatıya dâhil edilmiştir. Abluka' da distopik bir atmosfer elde etmek için seçilen gecekondu mahallesinin etrafı tıpkı birer parmaklık gibi Toki'ler ve göğe uzanan beton bloklarla çevrelenmiştir. Özellikle köpeklerin avlandığı dış çekim sahnelerde bu binaların silueti bunaltıcı ve tedirgin edici bir biçimde sunulur. Geçiş planlarında yine uzaktan baktığımız yeni İstanbul son derece çarpık, nefes almayan, beton bir çehreye sahiptir. Kentsel dönüşüm bir sorun olarak açıkça tartışıımasa da çarpık yapılaşmış ve hiç de insancıl olmayan bir biçimde betonlaşmış kentin kendisi bütün bunaltııılığıyla distopik bir mekân olarak ortadadır, "yaşanılası, mutlu ve huzurlu evrenin tersi, karabasanın, kâbusun, vahşetin ve terörün kol gezdiği bir yerdir." (Daldal, 2016, s. 94) Sarmaşık'ta ise kentsel dönüşüm Sulukule'deki yıkım örneğiyle açıkça ortaya konur.

Gemide yemek işlerini üstlenen Nadir'in en büyük derdi "evinin devlet tarafından yıkıması"dır. Beybaba tarafından "devlet hiç insanın evini yıkar mı?" diye terslenen Nadir, yıkım yüzünden ailesinin yanında olmak ister ama Beybaba

10 Bayraktar ve Erkılıç İstanbul'un kentsel dönüşümünü ve son yıllardaki inşaat faaliyetlerini konu alan Ekümenopolis: Ucu Olmayan Şehir (İmre Azem, 2011) belgeseli üzerine yaptıkları incelemede "kentsel dönüşümü, kenti rant olarak gören günümüz sistemini ve buna karşı koyan kentsel muhalefeti" (2015, s. 119) ele alan filmde bahsedilen mekansal pratiklerin aynı zamanda Gezi Olayları'nın habercisi olduğunu dile getirirler. Yazarların belirttiği gibi; "Sadece İstanbul'da değil, tüm Türkiye'de mekânın siyasal ve ekonomik elitler tarafından sömürülmesine dair isyan bir anda tüm ülkeyi etkisine almış ve eşi benzeri görülmemiş bir toplumsal eylemliliğin fitilini ateşlemişti" (2015, s. 125). Ayrıca Gezi Olayları ile ilgili bkz. Birikim, Gezi Direnişi: Bir Yanımız Bahar Bahçe. (Temmuz 2013). http://www.birikimdergisi.com/birikim/2462/291-292; Ayrıntı Dergi (Kasım-Aralık 2013). Dosya: "Gezi Direnişi: Yasak Delmek Sınır Aşmak". ; Yörük, Yüksel 2015. Kentsel dönüşüm için Bkz. Bartu Candan, Özbay 2014. 
onu "ailen için para kazanmalısın" diyerek ikna eder. Sulukule'deki yıkım görüntüleri gemideki televizyon ekranı aracılığıyla filme dâhil edilir. Krakauer'in belirttiği zamanın ruhu hem Sarmaşık hem hem de Abluka'da yıkımların ve baskıların bunalttığı karakterler aracılığıyla sinemaya yansır.

Delilik, iktidar ve hapishane kavramları üzerine önemli yapıtları bulunan Foucault, iktidarın gözetimi ve takibi temeline dayanan modern toplumlarda, büyük bir hapishane dokusunun toplumun içine dağılmış bir şekilde işlemekte olan disiplinsel düzenlemelerle bireyleri hapsettiğini öne sürer. (Foucault, 1992, s.382) Foucault'ya göre, fabrikalar, okullar, hastaneler devlet daireleri bu dokunun birer parçasıdır. İktidar güçleri tıpkı Jeremy Bentham'ın Panopticon hapishane modelinde olduğu gibi sürekli toplumun bireylerini görünmez yollarla izlemekte, sürekli izlendiği şüphesiyle yaşayan bireyler de kendilerini kendi zihinsel hapishanelerine kapatmaktadır. Abluka'da Kadir'in ya da Sarmaşık'ta İsmail'in muhbir olmayı kabul ederek bu izlemeye katılmaları ise onların korku ve paranoyaya sürüklenerek hapishanedekinden de beter bir tutsaklık yaşamalarına yol açar. Foucault hapishanenin kendisinin de toplumsal düzeni sağlamada etkili bir unsur olmadığından ve suçu beslediğinden de söz eder: "Hapishanenin suçluluğa yaptırım uyguladığı doğruysa da, bu suçluluk esas itibarıyle, hapishanenin nihai çözümlemede kendi hesabına sürdürdüğü bir kapatma tarafından ve bu kapatmanın içinde imal edilmektedir" (s. 384). Her iki filmde de hapsedilmişliğin etkisini arttırmasıyla yükselişe geçen şiddet bu fikri doğrular.

\section{Sonuç}

İçinde bulunduğumuz dönemde, 80'li yıllardan bu yana Türkiye Sineması'nda kendine pek çok bağlamda yer bulan hapsedilmişlik konusunu doğrudan ya da dolaylı olarak ele alan yapıtlarda dikkat çekici bir artış gözlemlenmektedir. Türkiye'de son yıllarda yaşanan hak ihlalleri ve politik baskılar konusunda sessiz kalmakla ve siyasi duyarsızlıkla eleştirilen Orhan Pamuk'un son romanı da Silivri Cezaevi'nde biter. Kırmızı Saç/ı Kadın'da kendisi üzerinde etkili olan toplumsal ruh halinden bahseden Orhan Pamuk otoritelik ve bireylik çatışmasının Türk Toplumu için bitmeyen bir konu olduğunu belirtir (Oskay, 2016). Ancak son dönemde artan otoriterlik karşısında filmler ve sanat eserleri bireysel özgürlüklerin ve düşünce özgürlügünün kısıtlanmasını daha çok sorgular hale gelmiştir. Otoritenin "Beybaba" gibi bir despot "baba" figürüyle simgeleştirildiği ve benliğini kazanamamış erkek kahramanların buhranlarının ele alındığı son dönem filmlerinin birçoğu (Çoğunluk, Seren Yüce 2010; Yeraltı, Zeki Demirkubuz, 2012; Yozgat Blues, Mahmut Fazıl Coşkun, 2013; Kış Uykusu, Nuri Bilge Ceylan, 2014 vd.) bu çerçevede incelenebilir.

Bu çalışmada incelediğimiz filmlerde de otoriter bir rejimin tahakkümü altındaki bireylerin haklarının ve özgürlüklerinin kısıtlanması ya da ellerinden alınması ve bu yolla bulundukları zamanın içinde esir edilmeleri karşısında verdikleri tepkinin gerçeklikten kopma, bir çeşit kabuğa çekilme ve içsel yolculuklara 
çıkarak, hayal ve düş evrenine sığınma olduğu söylenebilir. Karakterlerinkine benzer bir yaklaşımla, incelediğimiz filmlerin sinemacıları da içinde bulunduğumuz toplumsal-politik ortamın yarattığı baskılar ve bunalımlar karşısında klasik gerçekçi politik anlatılar kurgulamak yerine hayal ve düşten beslenen, distopik, fantastik, alegorik, dışavurumcu öğelerin ve bireysel hikâyelerin öne çıktığı postmodern yaklaşımları tercih etmektedirler. Emin Alper bu yaklaşımı şu sözleriyle özetler:

\begin{abstract}
"Politik bir hikâyeyi politik olmayan karakterler üzerinden anlatmak heyecan verici bir şey çünkü size insana dair bir şeyler anlatma imkânı da sunuyor. Mahallede işlenmiş suçların faillerini ortaya çıkarmaya çalışan bir gazetecinin yahut insan hakları aktivistinin hikâyesi ya da politik bilince sahip karakterlerin gözünden anlatılmış bir hikâye, güncel politik durum hakkında daha fazla laf üretirdi belki; ama alışımışın dışında bir perspektif beni hem politik hem estetik açıdan daha fazla ilgilendiriyor. Bu politik evrene ilk bakışta hiç akla gelmeyecek iki karakterin gözünden bakmak ve bir yıkım hikâyesini, polis devletinin insanları sürüklediği delilik üzerinden anlatmak bana çok daha ilginç geliyor". (Çiftçi, Göl, 2015, s. 22)
\end{abstract}

İçinde yaşanan karamsar ruh halinden, sansür ve otosansürün etkilerinden ve post modernliğin izlerini taşıyan bireysellik arayışlarından bağımsız düşünülemeyecek bu sinemasal yaklaşım Alper ve Karaçelik'in filmlerinde seyircisinden de çaba bekleyen açık uçlu bir yapıya sahiptir. Sonuç olarak zihinleri saran ön kabuller ve düşünsel ablukalar üzerine bir düşünme alanı sunan her iki film de Türkiye Sineması'nın toplumdaki özgürlük arayışlarını bir kez daha perdeye yansıtır.

\title{
Film Künyeleri
}

\author{
Abluka \\ Yönetmen: Emin Alper \\ Senaryo: Emin Alper \\ Yapımcı: Nadir Öperli, Cem Doruk, Doruk Acar , Enis Köstepen \\ Müzik: Cevdet Erek \\ Görüntü Yönetmeni: Adam Jandrup , Yavuz Abdülazizoğlu \\ Oyuncular: Mehmet Özgür, Berkay Ateş, Tülin Özen \\ Vizyona Giriş Tarihi: 06 Kasım 2015 \\ Süre: $119 \mathrm{dk}$ \\ Ülke: Fransa Katar Türkiye
}

\section{Sarmaşık}

Yönetmen: Tolga Karaçelik

Senaryo: Tolga Karaçelik

Yapımcı: Bilge Elif Turhan

Müzik: Ahmet Kenan Bilgiç

Görüntü Yönetmeni: Gökhan Tiryaki

Oyuncular: Nadir Sarıbacak, Özgür Emre Yılırım, Kadir Çermik 
Vizyona Giriş Tarihi: 04 Aralık 2015

Süre: $104 \mathrm{dk}$

Ülke: Türkiye

\section{Kaynakça}

Arslan U. T, Göral S. (16 Ocak 2016). Abluka. Birikim. Erişim 01.03.2016, http:// www.birikimdergisi.com/guncel-yazilar/7458/abluka\#.V1AcgfmLSM8

Bartu Candan A., Özbay C. (haz.) (2014). Yeni İstanbul Çalışmaları, İstanbul: Metis.

Bayrak Akyıldız H. (Güz 2009). Tanpınar'da Roman Tekniği Açısından Rüya ve Müzik. Milli Eğitim.

Bayraktar S. U., Erkılıç H. (Aralık 2015). Ekümenopolis: Resimli ve Temsili Bir Triyalektik Mekan Okuması Olarak Ekümenopolis. İleti-ş-im. 23, 113-134.

Çiftçi A., Göl B. (Kasım 2015). Distopik Karabasan, Emin Alper ile Söyleşi. Altyazı.

Daldal A. (Mart 2016). Kaligari'den Hitler'e, Distopyalardan Yeni Türkiye'ye. Birikim.

Duncan P. (2006). Film Noir: Films of Trust and Betrayal, Pocket Essentials.

Edener E. (Aralık 2015). Denizin Zamansızığı, Tolga Karaçelik ile röportaj, Altyazı.

Emin Alper'le Söyleși. Türkiye Film Araștırmalarında Yeni Yönelimler Konferansı XVII "Sinema ve Zaman". 7 Mayıs 2016. Kadir Has Üniversitesi, İletişim Fakültesi

Fischer S., McGowan M. (1996). From Pappkoffer to Pluralism. Turkish Culture in German Society Today, Oxford: Berghahn Books.

Foucault M. (1995). Deliliğin Tarihi. (M. A. Kılıçbay, Çev.). Ankara: İmge.

Foucault M. (1992). Hapishanenin Doğușu : Gözetim Altında Tutmak ve Cezalandırmak, (M. A. Kılıçbay, Çev.), Ankara: İmge.

Göktürk D. (2000). Turkish Women on German Streets : Closure and Exposure in Transnational Cinema. M. Konstantarakos (Ed.). Spaces in eurepean cinema içinde. Portland-Exeter: Intellect.

Naficy H. (Temmuz 1994). Phobic Spaces and Liminal Panics: Independent Transnational Film Genre. East-West Film Journal. Honolulu: East-West Center, Chicago Press.

Naficy H. (2001). An Accented Cinema: Exilic and Diasporic Filmmaking. Princeton: Princeton University Press.

Oskay C.. (31.01.2016). Orhan Pamuk: Can Dündar Tutuklanırken Oturup Romanını Yazamıyorsun. Orhan Pamukla Söyleşi, Radikal. Erişim 10.05.2016, http://www. 
radikal.com.tr/turkiye/orhan-pamuk-can-dundar-tutuklanirken-oturup-romaniniyazamiyorsun-1502515/

Özön N. (1981). Sinema ve Televizyon Terimleri Sözlügü. Ankara: TDK Yayınları.

Paça Cengiz E. (2016). "Kurul(a)mayan Hikayeler, Anlatıl(a)mayan Geçmişler: Sinemada 12 Eylül", Türkiye Sinema Araştırmalarında Yeni Yönelimler XII, İstanbul: Bağlam.

Par K. (01.10.2015). Abluka' ile Venedik'ten Ödülle Dönen Emin Alper: Filmin Uğursuz Olduğunu Düşünmeye Başladım, Emin Alper'le Söyleşi. Erişim 07.04.2016, http://t24.com.tr/haber/abluka-ile-venedikten-odulle-donen-eminalper-filmin-ugursuz-oldugunu-dusunmeye-basladim,314903

Silver A., Elisabeth M. Ward (ed.). (1992). Film Noir. An Encyclopedic Reference to the American Style. Woodstock, NY : Overlook Press.

Sorlin P. (1977) Sociologie du cinéma, ouverture pour l'histoire de demain, Paris: Ed. Aubier-Montaigne.

Tanpınar A. H. (ilk basım 1969, 2005) Edebiyat Üzerine Makaleler, Z. Kerman (Haz.). İstanbul : Dergah Yayınları.

Yörük, E. ve Yüksel, M. (2015). Gezi Eylemlerinin Toplumsal Dinamikleri. Toplum ve Bilim. 133. 132-165. 